\title{
Tradisi Ritual Kupatan Jalasutra Di Srimulyo, Piyungan, Bantul, Yogyakarta
}

\author{
R. Jati Nurcahyo ${ }^{1)}$, Yulianto ${ }^{2)}$ \\ Universitas Bina Sarana Informatika \\ Email : r.jno@bsi.ac.id ${ }^{11}$, yulianto.ylt@bsi.ac.id ${ }^{2)}$
}

\begin{abstract}
In the cultural perspective, the society in Jalasutra village, Piyungan, Bantul, Yogyakarta has auniqueness. The substance lies on the belief system, traditional custom and culture which are reflected in various traditional ceremonies. The research about society ritual and belief in Jalasutra, Srimulyo, Piyungan, Bantul, Yogyakarta is motivated by the fact that the meaning and value of this remarkable ritual in a society is very important. Ritual and belief are the demands of life that can shape the society behavior. They are parts of tradition and custom exist in the lives of society. Objectively, the description of culture system in Jalasutra society is a positive contribution to strengthen the identity and personality to reach the national integrity and increase the tourism industry in Indonesia.
\end{abstract}

\section{Keywords : Tradition, Kupatan Jalasutra Ritual Ceremony}

Abstrak - Dalam perspektif kultural masyarakat di desa Jalasutra, Piyungan, Bantul, Yogyakarta mempunyai keunikan. Substansinya terletak pada sistem kepercayaan, adat tradisi dan budaya yang terungkap dalam berbagai penyelenggaraan upacara tradisional. Penelitian tentang bentuk ritual dan kepercayaan masyarakat di Jalasutra, Srimulyo, Piyungan, Bantul, Yogyakarta terdorong oleh suatu kenyataan akan pentingnya arti dan makna sebuah ritual yang sangat langka dalam suatu kehidupan masyarakat. Ritual dan kepercayaan merupakan suatu tuntutan kehidupan guna menentukan perilaku yang sudah menjadi bagian dari adat tradisi dan membudaya di masyarakat. Secara obyektif, deskripsi tentang sistem budaya dikalangan masyarakat Jalasutra tersebut merupakan kontribusi positif untuk upaya memperkokoh jatidiri dan kepribadian masyarakat menuju tercapainya integritas bangsa dan dunia kepariwisataan di Indonesia.

Kata Kunci : Tradisi, Upacara Ritual Kupatan Jalasutra

\subsection{Pendahuluan}

Salah satu desa yang terdapat di Kecamatan Piyungan Bantul Yogyakarta adalah desa Srimulyo. Adapun letaknya berada disebelah barat dari Kecamatan Piyungan yang berjarak 1,5 km, sedangkan dengan Kabupaten Bantul berada disebelah timur laut berjarak 22 $\mathrm{km}$. Lingkungan alam terhadap bentuk permukaan tanah (medan) desa Srimulyo sebagian besar berupa perbukitan dan selebihnya adalah dataran. Ketinggian rata-rata 115 meter diatas permukaan air laut. Berdasarkan peta geologi Daerah Istimewa Yogyakarta skala 1:250.000 berupa endapan vulkanik gunung api muda. Adapun jenis tanahanya kambisial dengan batuan atau bahan induk endapan material vulkanis dan tingkat produktifitas tanah sedang.

Di Desa Srimulyo terdapat dusun bernama Jalasutra yang sampai saat ini masih melaksanakan upacara ritual tradisional yang dikenal dengan Kupatan Jalasutra diselenggarakan sedekah panen padi satu kali dalam setahun dengan memilih hari Senin Legi. Sedangkan tanggal pelaksanaanya berdasarkan pedoman penanggalan kalender jawa yaitu antara tanggal 10 sampai dengan 15 saat menjelang bulan purnama.
Dalam era pasca modern ini, meskipun muncul isu tentang wacana perubahan yang menyebabkan batasan masyarakat menjadi kabur terhadap adat tradisi dan budayanya. Namun keberadaan upacara Ritual Kupatan di Jalasutra, Srimulyo, Piyungan, Bantul, Yogyakarta sampai saat ini masih ditemukan dalam kehidupan masyarakat. Biasanya kultur mereka dijadikan pedoman hidup bermasyarakat karena mengandung nilai-nilai religious dalam kehidupan sosiokultural.

Upacara ritual adat tradisi merupakan bagian dari wacana dengan apa sentiment kemasyarakatan tersebut dapat diekspresikan secara kolektif dan berulang pada saat-saat tertentu. Hal ini penting sebagai penguat solidaritas sosial, sehingga mampu membuka ruang terciptanya integritas dalam sistem sosial masyarakat.

Tradisi ritual Kupatan Jalasutra berkaitan erat dengan upaya pengungkapan, pelestarian dan penyebarluasan nilai-nilai budaya yang luhur. Maksud dan tujuan dari ritual Kupatan Jalasutra yaitu sebagai ungkapan rasa syukur kepada Tuhan Yang Maha Esa dan Nabi Muhammad SAW serta para leluhur yang telah melimpahkan karunia-Nya, sehingga hasil pertanian warga masyarakat Srimulyo berhasil dengan baik. Keberhasilan hasil panen 
merupakan peristiwa yang sangat diharapkan oleh masyarakat. Oleh karenanya masyarakat merasa wajib mengucapkan syukur kepada Tuhan Yang Maha Esa.

\subsection{Kajiaan Pustaka}

Tradisi adalah kesamaan benda material dan gagasan yang berasal dari masa lalu namun masih ada yang hingga kini dan belum dihancurkan atau dirusak. Namun demikian tradisi yang terjadi berulang-ulang bukanlah dilakukan kebetulan atau disengaja (Sztompka: 2007). Sedangkan secara terminologi perkataan tradisi mengandung suatu pengertian yang tersembunyi tentang adanya kaitan masa lalu dengan masa kini. Tradisi merupakan bagian dari kebudayaan yang menggambarkan bagaimana dalam suatu masyarakat bertingkah laku.

Tradisi ritual yang masih banyak ditemukan dibeberapa daerah di Indonesia, khusunya tradisi ritual Kupatan Jalasutra sangat berkaitan dengan lingkaran hidup manusia berupa aktifitas kehidupan sehari-hari dalam mencari nafkah, terlebih yang berprofesi sebagai petani. Upacara ritual tersebut pada uunya dilakukan dengan harapan pelaku upacara agar hidup senantiasa dalam keadaan sehat (Darori Amin :2000),

Menurut Shils dalam Piotr Sztompka mengatakan bahwa manusia tidak mampu hidup tanpa tradisi meski mereka sering merasa tak puas terhadap tradisi mereka. Shils menjelaskan lebih lanjut bahwa suatu tradisi memiliki fungsi bagi masyarakat diantaranya :

1. Dalam bahasa klise dinyatakan, tradisi adalah kebijakan turun-temurun.

2. Memberikan legitimasi terhadap pandangan hidup, keyakinan, pranata dan aturan yang sudah ada.

3. Memberikan simbol identitas kolektif yang meyakinkan, memperkuat loyalitas primordial terhadap bangsa, komunitas dan kelompok.

4. Membantu menyediakan tempat pelarian dari keluhan, kekecewaan dan ketidakpastian kehidupan modern.

Seperti halnya tradisi ritual Kupatan Jalasutra merupakan gagasan dan material yang dapat dilakukan oleh orang lain atas tindakan kini dan dalam membangun masa depan yang dilakukan dalam tujuan untuk menangkal pengaruh buruk yang tidak dikehendaki dan dapat membahayakan bagi kelangsungan kehidupan masyarakat Srimulyo atas hasil panen mereka.

Tradisi dan agama sangatlah berbeda, namun kerap kali menimbulkan perdebatan khusus dalam masyarakat. Terdapatnya upacara atau kegiatan tradisi dibeberapa daerah di Indonesia dianggap kurang beragama. Dalam hal ini, agama lebih jelas tujuannya dan terdapat aturan-aturan hukum agama didalamnya yang tertuju hanya kepada Tuhan Yang Maha Esa. Sementara tradisi merupakan suatu bentuk kegiatan yang sudah dipercaya oleh masyarakat dan berlangsung secara turun-temurun dapat dimaknai bahwa tujuannya untuk kepentingan duniawi. (Suwardi : 2012)

\subsection{Metode Penelitian}

Dalam penelitian ini menggunakan analisis deskriptif kualitatif. Deskriptif adalah melakukan penelitian dengan cara menjabarkan suatu masalah secara deskriptif. Penulisan dilakukan dengan penjelasan kata-kata yang mudah dipahami bukan dalam bentuk angka (Azwan : 2010). Kesimpulan yang dihasilkan harus sesuai fakta yang ada sehingga semua dapat dikembalikan langsung pada data yang diperoleh. Sedangkan data kualitatif adalah analisis yang menekankan pada menjawab pertanyaan mengenai fungsi tradisi ritual Kupatan Jalasutra di Srimulyo Piyungan Bantul Yogyakarta sehingga mampu sebagai penguat solidaritas sosial masyarakat.

Data selanjutnya dikumpulkan dengan beberapa teknik yaitu wawancara secara mendalam, observasi dan studi pustaka. Wawancara dilakukan yang mendalam kepada para tokoh pendukung upacara tradisi ritual, sesepuh desa, para petugas yang terlibat dalam pelaksanaannya maupun warga masyarakat yang sekiranya mengetahui tentang tradisi ritual Kupatan Jalasutra. Dalam proses wawancara dipilih dua informan kunci yaitu Bapak Drs. Wajiran (Kepala Desa Srimulyo) dan Ibu Widayati, S.Pd (Ketua TP PKK Srimulyo). Sedangkan observasi dilakukan dengan cara mengamati langsung jalannya upacara tradisi ritual Kupatan Jalasutra tersebut mulai dari persiapan sampai akhir kegiatan. Dan studi pustaka dilakukan dengan mencari sumber referensi buku yang terkait. Sementara analisis data dilakukan dengan beberapa langkah yaitu mengorganisir informasi atau data yang sudah dikumpulkan dari beberapa sumber, melakukan reduksi data, melakukan interpelasi dan mengembangkan generalisasi natural untuk peneliti maupun untuk penerapan pada kasus yang lain serta menyajikan secara naratif.

\subsection{Hasil Dan Pembahasan}

Suatu upacara tradisional adalah bagian terintegral dari kebudayaan masyarakat pendukungnya untuk kelestarian hidupnya ditentukan atas fungsi bagi kehidupan masyarakat tersebut. Penyelenggaraan upacara tradisional sangat berarti bagi pembinaan sosial budaya warga masyarakat di desa Jalasutra, Srimulyo, Piyungan, Bantul, Yogyakarta. Hal ini 
dikarenakan salah satu fungsi dari upacara tradisional sebagai penguat norma-norma dan nilai-nilai budaya yang telah ada dan berlaku sejak dulu. Norma-norma dan nilai-nilai budaya tersebut secara simbolis ditampilkan dalam berbagai bentuk upacara tradisi yang dilakukan oleh seluruh warga masyarakat. Yang dapat membangkitkan rasa aman bagi setiap warga masyarakat dilingkungannya dan menentukan sikap dan tingkah laku sehari-hari. Upacara tradisional sebagai salah satu kegiatan sosial menjadikan pelindung bagi norma-norma sosial dan nilai-nilai didalam kehidupan kultur masyarakat pendukungnya yang mana cepat atau lambat akan mengalami hal yang sama yaitu hilang atau musnah. Apabila hal ini tidak dilestarikan oleh masyarakat pendukungnya karena dianggap sudah tidak mempunyai fungsi lagi.

Upacara tradisi ritual Kupatan Jalasutra merupakan salah satu bentuk ungkapan budaya yang banyak memuat nilai-nilai kearifan budaya masyarakat lokal yang dapat diteladani dan dapat diinternalisasi oleh generasi penerus. Sistem nilai pada hakekatnya menjadikan posisi sentral terhadap struktur budaya dari suatu masyarakat. Karena sistem nilai tersebut berupa perangkat struktur dalam kehidupan manusia secara individu ataupun sosial. Demikian pula halnya nilai-nilai yang terkandung dalam upacara tradisi ritual Kupatan Jalasutra menjadikan fenomena dan problematik dasar dalam kehidupan masyarakat di Jalasutra Srimulyo Piyungan Bantul Yogyakarta, yang kemudian upacara tradisi ritual Kupatan Jalasutra tersebut eksis dilakukan oleh masyarakat lokal setempat dan masyarakat Yogyakarta pada umumnya karena dinilai mengandung arti dan makna tersendiri.

Terdapat beberapa hal yang berupa nilainilai budaya dari upacara tradisi ritual Kupatan Jalasutra yang dapat diambil untuk diteladani, yaitu :

1. Penghormatan terhadap Tuhan Yang Maha Esa

Dalam rangkaian upacara tradisi ritual Kupatan Jalasutra diawali dengan memanjatkan doa ungkapan puji syukur kepada Tuhan Yang Maha Esa da memohomn perlindungan, keselamatan dan nikmat yang telah diberikan-Nya kepada masyarakat Srimulyo Piyungan Bantul Yogyakarta,

2. Penghormatan terhadap leluhur

Keberhasilan panen di desa Srimulyo Piyungan Bantul Yogyakarta tidak dapat dilepaskan atas peran para leluhur terdahulu yang telah berhasil menciptakan dan mengolah lahan tandus menjadi lahan persawahan yang menghijau. Upacara tradisi ritual Kupatan Jalasutra pada awalnya dimulai sejak Sunan Geseng hidup sampai wafatnya beliau yang berkediaman di wilayah desa Srimulyo Piyungan Bantul Yogyakarta. Sunan Geseng bernama asli adalah Cakrajaya adalah murid Sunan Kalijaga dan atas bimbingannya, maka Sunan Geseng mempunyai kelebihan ilmu termasuk bidang pertanian, disamping bidang keagamaan Islam. Kelebihan Sunan Geseng inilah yang kemudian oleh masyarakat di Srimulyo dijadikan panutan dan teladan. Guna mengenang jasa-jasa para leluhur, masyarakat di Srimulyo memberikan penghormatan dengan cara membersihkan makam-makam leluhur dan selanjutnya mengirim doa melalui sedekah bersama berupa "Kendhuri".

3. Aset Wisata Religi

Upacara tradisi ritual Kupatan Jalasutra sudah menjadi aset wisata religi di Yogyakarta yang setiap tahun pelaksanaan penyelenggaraannya selalu mendapatkan apresiasi positif oleh banyak pengunjung baik dari Yogyakarta maupun dari luar wilayah Yogyakarta. Biasanya setiap pengunjung yang dapat dalam upacara Kupatan Jalasutra akan membeli ketupat sebagai oleh-oleh atau tanda bahwa mereka baru saja mengikuti suatu upacara tradisi Kupatan Jalasutra. Dalam hal ini banyak hal yang dipetik oleh masyarakat dan pemerintah desa setempat bahwa dengan hadirnya pengunjung dari wilayah Srimulyo, maka berbagai potensi lain yang asli dari Srimulyo dapat diperkenalkan dan dapat dilakukan transaksi jual beli, seperti : hasil olahan pangan lokal, batik tulis pewarna alam, hasil pertanian, perkebunan, hasil kerajinan dan lain sebagainya. Yang pada akhirnya sedikit banyak dapat meningkatkan taraf kesejahteraan masyarakat setempat.

4. Pelestarian lingkungan

Wilayah daerah Srimulyo yang semual dikenal sebagai salah satu wilayah tandus di Yogyakarta dan sulit untuk ditanami padi. Dalam perkembangannya, akhirnya dapat ditanami tanaman padi dan menjadikan lahan tandus berubah menjadi lahan yang menghijau dan produktif. Upaya penghijauan selalu digerakkan dan mendapatkan sambutan yang baik oleh warga masyarakat Srimulyo. Untuk beberapa lokasi yang tidak memungkinkan ditanami padi, oleh masyarakat kemudian ditanami berbagai buah seperti jambu mete, mangga, jambu biji, duwet, durian dan lain sebagainya. Hal ini sudah sejalan dengan program pemerintah yaitu untuk dapat merawat, 
mengelola dan menjaga kelestarian lingkungan hidup.

5. Gotong Royong

Dengan dilibatkannya secara langsung masyarakat Srimulyo dalam pelaksanaan upacara tradisi ritual Kupatan Jalasutra dari perencanaan awal sampai berakhirnya upacara membuktikan bahwa semangat kegotong royongan masyarakat Srimulyo masih sangat kuat. Kegiatan gotong royong sudah merupakan aktivitas yang membudaya di masyarakat Srimulyo dan hal ini dilakukan karena warga masyarakattergerak untuk selalu maju dan tidak ingin tertinggal oleh daerah lainnya dalam berbagai bidang.

6. Unsur Taat dan Patuh

Warga masyarakat Jalasutra Srimulyo Piyungan Bantul sejauh ini masih sangat taat dan mematuhi berbagai peraturan ataupun ketentuan terhadap kelancaran dan keberlangsungan upacara tradisi ritual Kupatan Jalasutra. Hal ini dapat diamati kaitannya dengan Hari dan Tanggal pelaksanaan dari upacara tersebut. Mereka tidak berani melanggar denga mengganti hari dan tanggal pelaksanaan upacara tradisi ritual Kupatan Jalasutra atau bahkan menghentikan upacara tersebut. Unsur ketaatan juga dapat terlihat dengan jelas bahwa warga masyarakat Jalasutra masih secara detail mempersiapkan berbagai macam sesajian yang ada.

Bentuk sesaji dan makna simbolik dari upacara tradisi ritual Kupatan Jalasutra sebagai berikut:

1. Nasih Gurih

Berupa nasih putih yang dimasak dengan menggunakan santan dan bumbu rempah gurih. Adapun maknanya adalah persembahan rasa syukur dari warga masyarakat Jalasutra Srimulyo Piyungan Bantul Yogyakarta kepada Tuhan Yang Maha Esa dan para leluhur karena hasil panennya telah menjadikan berkah dan kenikmatan untuk semua masyarakat.

2. Ingkung

Berupa ayam jantan yang diolah secara utuh dengan menggunakan santan dan bumbu rempah gurih. Adapun maknanya adalah manusia dilahirkan dalam keadaan suci dan selalu berserah diri kepada Tuhan Yang Maha Esa.

3. Hasil Pertanian

Berupa padi, jagung, ketela pohon, ubi-ubian dan lain-lain. Adapun maknanya rasa syukur atas rahmat Tuhan Yang Maha Esa yang telah memberikan hasil pertanian dan palawija bagi masyarakat di Srimulyo.

4. Jajan Pasar
Berupa berbagai makanan yang didapat dari pasar. Adapun maknanya diharapkan masyarakat Srimulyo mendapatkan berkah dari Tuhan Yang Maha Esa yang bertepatan dengan hari baik saat pelaksanaan upacara tradisi ritual Kupatan Jalasutra.

5. Puthu Kering

Berupa makanan yang disebut dari bahan beras ketan yang digoreng hingga berwarna hitam, selanjutnya ditumbuk dan diberi gula jawa dicetak bulat kecil. Adapun maknanya bahwa Sunan Geseng selalu melekat pada diri warga masyarakat Jalasutra.

6. Kupat atau Ketupat

Berupa makanan yang dibuat dari bahan beras dan ditempatkan pada wadah berbahan janur. Adapun maknanya mangku papat bahwa masyarakat pendukung upacara tradisi ritual Kupatan Jalasutra untuk tetap menjaga persatuan, kesatuan, kesadaran dan kegotong-royongan.

\subsection{Kesimpulan Dan Saran}

Upacara tradisi ritual Kupatan Jalasutra merupakan salah satu aset budaya dan pariwisata di Indonesia, khususnya di Yogyakarta yang perlu dilestarikan karena didalamnya mengandung nilai-nilai luhur yang sepantasnya untuk dapat diteladani. Dalam perspektif kultural masyarakat di desa Jalasutra, Piyungan, bantul, Yogyakarta mempunyai keunikan. Substansinya terletak pada sistem kepercayaan, adat tradisi dan budaya yang terungkap dalam berbagai penyelenggaraan upacara tradisional.

Bentuk tradisi ritual yang dipercaya oleh masyarakat di Jalasutra, Srimulyo, Piyungan, Bantul, Yogyakarta adalah suatu kenyataan yang masih dapat ditemukan di Jawa khususnya Daerah Istimewa Yogyakarta terhadap pentingnya arti dan makna sebuah tradisi ritual yang sangat langka dalam suatu kehidupan masyarakat. Hal ini dikuatkan dengan adanya bentuk sesajian yang tidak ditemukan daerah lain, berupa : nasi gurih, ingkung, hasil pertanian, jajan pasar, puthu kering dan ketupat. Yang mana bentuk tradisi ritual tersebut merupakan suatu tuntutan kehidupan masyarakat di Desa Jalasutra, Srimulyo, Piyungan, Bantul Yogyakarta guna menentukan perilaku yang sudah menjadi bagian dari adat tradisi dan telah membudaya di masyarakat.

Oleh masyarakat sekitar, upacara tradisi ritual Kupatan Jalasutra dirasakan mampu membawa dampak positif bagi keberlanjutan ekonomi dan terbukanya lapangan kerja bervariatif baik warga masyarakat lokal maupun dari luar daerah Srimulyo yang masih sangat membutuhkan penanganan dan termasuk Sumber Daya Manusianya agar tetap siap dan 
mampu mengembangkan potensi tradisi, potensi diri berupa ketrampilan dalam membikin berbagai bentuk sesajian dan souvenir serta keahlian dalam bidang pertanian. Yang pada akhirnya diharapkan dapat membawa dampak positif pada kesejahteraan masyarakat di Desa Jalasutra, Srimulyo, Piyungan, Bantul Yogyakarta.

Secara obyektif, deskripsi tentang sistem budaya tradisi dikalangan masyarakat Jalasutra tersebut merupakan kontribusi positif untuk upaya memperkokoh jatidiri dan kepribadian masyarakat menuju tercapainya integritas bangsa dan dunia kepariwisataan di Yogyakarta.

Adapun saran yang dapat disampaikan diantaranya bahwa :

1. Perlu adanya kerjasama dan penataan kelembagaan yang konkret antara masyarakat lokal, pemerintah daerah dan pengelola.

2. Perlu diciptakan penguatan kualitas produk lokal yang khas dalam pengembangannya

3. Guna meminimalisir dampak negatif terhadap budaya lokal asli daerah, maka diperlukan adanya edukasi informasi dan arahan lebih lanjut dari pihak-pihak terkait kepada para pengunjung atau wisatawan.

4. Langkah pembinaan dibidang spiritual (belief system) dari pihak manapun jangan sampai menghilangkan atau meniadakan nilai-nilai tradisi yang adiluhung (local genius).

5. Perpaduan sinergis antara religi yang di anut oleh masyarakat di Srimulyo Piyungan Bantul Yogyakarta dengan tradisi ritual Kupatan Jalasutra, merupakan kontribusi yang signifikan untuk menjaga kelestarian tradisi lokal masyarakat Jalasutra dengan dunia kepariwisataan di Indonesia.

\section{Daftar Pustaka}

[1] Amin, Darori, 2000. Islam dan Kebudayaan Jawa. Yogyakarta : Gema Media.

[2] Azwar, 2010. Metodologi Penelitian. Jakarta : Pustaka Pelajar Offset

[3] Irwan, Abdullah, 2002. Simbol, Makna dan Pandangan Hidup Jawa: Analisis Gunungan Pada Upacara Garebeg. Yogyakarta: BPST.

[4] Mulyadi, 2009. Upacara Tradisional Sebagai Sosialisasi DIY. Yogyakarta: Proyek P2NB Dekdikbud.

[5] Suwardi, Endaswara, 2012. Filsafat Sastra: Hakikat, Metodelogi dan Teori. Yogyakarta: Layar Kata.

[6] Solikhin, KH. Muhammad, 2010. Ritual dan Tradisi Islam Jawa. Yogyakarta : Narasi, Cet.1

[7] Sztomka, Piotr, 2007. Sosiologi Perubahan Sosial. Jakarta: Prenada Media Group. 